\title{
Dossiê II Encontro do GT Filosofia e Gênero
}




\section{Apresentação do dossiê II Encontro do GT Filosofia e Gênero}

Leitoras e leitores encontram nesse número dos Cadernos de Ética e Filosofia Política uma seleção de artigos dedicados à pesquisa sobre filosofia e gênero, a maioria deles fruto do II Encontro do Grupo de Trabalho de Filosofia e Gênero da Anpof, realizado entre os dias 04 e 06 de setembro de 2019, no Departamento de Filosofia da FFLCH/USP. A seleção é uma importante contribuição para a pesquisa na área e segue algumas prerrogativas fundamentais que marcam a fundação do referido Grupo.

Criado em 2016, o GT de Filosofia e Gênero pretende preencher, assim como outras iniciativas no campo de pesquisa em filosofia, uma lacuna fundamental: o fomento e a divulgação da produção tanto de pensamento feminista como de obras filosóficas escritas por mulheres. Tratase de reconhecer que a história da filosofia não é nem nunca foi feita só por homens e, em decorrência disso, de dar espaço às pesquisas que abordem a reflexão filosófica produzida por mulheres, aos estudos dedicados ao debate sobre gênero e epistemologias feministas, às diferentes discussões sobre colonialidade, às investigações da estética e da crítica de arte feministas, aos trabalhos que abordem éticas feministas, e às pesquisas que tratem do olhar misógino da filosofia canônica sobre as mulheres.

Esse amplo espectro de investigação pode ser encontrado no presente número, de modo que a publicação expressa resultados recentes dessa importante iniciativa coletiva de pesquisa, realizada, decerto, no contexto dos Programas de Pós-graduação de todas as regiões do país. Além dos artigos, a seleção conta também com a tradução de um ensaio de Judith Butler, "Gênero em tradução: além do monolinguismo"; e com a obra da artista negra paulistana Rosana Paulino, que gentilmente nos cedeu a imagem de Mãe e filha cegas para ilustrar a capa do dossiê.

Agradecemos também, além do trabalho de padronização e revisão da equipe editorial dos Cadernos de ética e filosofia política, o auxílio de Iracy Ferreira dos Santos Junior, Luana Alves dos Santos, Vitor Frohlich, Lucas Paolo Vilalta, Lucas Bittencourt Vasconcellos, Ricardo Polidoro Mendes, Mariana Di Stela Piazzolla, Mario Antunes Marino e Melissa Otsuka, que participaram do processo de revisão dos textos.

É sem dúvida uma alegria e uma realização de grande monta a edição desse número dos Cadernos de Ética e Filosofia Política, o qual pôde contar com a colaboração de pessoas empenhadas no estudo das questões de gênero sob a ótica da filosofia e, também, da arte. Esperamos que leitoras e leitores possam desfrutar do material aqui compilado e agradecemos às autoras e aos autores que contribuíram para que esse número chegasse ao público.

Boa leitura!

Silvana de Souza Ramos

Clêmie Ferreira Blaud 